\title{
A comparative study of mentoring for new teachers
}

\author{
Rachel Shanks ${ }^{a *}$, Michelle Attard Tonna ${ }^{\mathrm{b}}$, Frede Krøjgaard ${ }^{\mathrm{c}}$, Karen \\ Annette Paaske ${ }^{\mathrm{c}}$, Dean Robson ${ }^{\mathrm{a}}$ and Eva Bjerkholt ${ }^{\mathrm{d}}$
}

${ }^{a}$ School of Education, University of Aberdeen, Aberdeen, UK; ${ }^{b}$ Faculty of Education, University of Malta, Msida, Malta; 'School of Education, VIA University College, Copenhagen, Denmark; ${ }^{d}$ Faculty of Humanities, Sports and Educational Science, University of South-Eastern Norway, Notodden, Norway.

*r.k.shanks@abdn.ac.uk

School of Education, MacRobert Building, King's College, University of Aberdeen, Aberdeen AB24 5UA, Scotland. Tel: +44 (0)1224 274871

\section{Rachel Shanks}

Rachel Shanks is a Senior Lecturer in the School of Education at the University of Aberdeen. She researches professional learning, in particular informal learning and mentoring and is also interested in children and young people's rights. Rachel is a co-convenor of the Open Learning network of the European Educational Research Association (network 6) and is on the governing body of the Scottish Educational Research Association. She is a Senior Fellow of the Higher Education Academy and is a member of the Scottish Community Learning and Development Standards Council. Rachel previously had a varied career in research and education including positions as a law lecturer; employment rights adviser; and as a lifelong learning organiser.

\section{Michelle Attard Tonna}

Michelle Attard Tonna is Deputy Dean of the Faculty of Education, University of Malta and she coordinates school-based mentoring on a national level. This role entails overseeing the mentoring of student-teachers during their field placement whereby teachers based in schools are trained to be mentors. Before occupying this role, she was engaged by the Ministry for Education and Employment as Head of Project in the Learning Outcomes Framework, coordinating a national project on the introduction of learning outcomes in the curriculum. She has also represented the Ministry in a number of working groups and fora, both locally and 
internationally. Her primary research interests include the professional development of teachers and comparative studies of the way teachers learn. She has contributed to various Europeanwide studies in the area of teacher learning and participated in various conferences and European networks in which she has presented her research. She has published her work in a number of educational journals and books, mostly focusing on teachers, their perceptions, their professional growth and their role as leaders in schools. She has completed a $\mathrm{PhD}$ with the University of Aberdeen, UK, basing her research on professional teacher professional learning in Malta.

\section{Frede Krøjgaard}

Frede Krøjgaard is a Senior Lecturer at VIA University College Denmark. He researches professional learning with a special interest in newly qualified teachers' early development and is also interested in the education of Maths resource staff and the evolution of their role in the Danish Folkeskole. Frede is a former chair of SEMAT, the Association of Teacher Training Maths Teachers in Denmark and former member of the Maths judgment committee for lecturers at teacher training institutes. He has a broad experience in school development in Denmark and a special experience of consulting school development from consulting the development of a group of approximately 100 schools in Tamil Nadu, India over a 10 year period.

\section{Karen Paaske}

Karen Annette Paaske is a Senior Lecturer in VIA University College Denmark. She researches in Counselling and mentorship, particularly in relation to the professional development of teachers and nurses. She is coordinator of a research programme that works with teacher induction programmes. Karen is also an external lecturer at Aarhus University for the Masters in Counselling. Karen has the role of judge chairman for the Danish qualification of lecturer. She is a working censor in several Bachelor programmes and on Masters degrees. Karen acts as a member of the Danish Qualifications Board, where she decides on merit cases. Karen's Ph.D. degree is from Aarhus University and focused on the use of IT in counselling.

\section{Dean Robson}


Dean Robson is a Senior Lecturer in the School of Education at the University of Aberdeen. He is currently Programme Director for the Masters in Education (flexible pathway) offered by the School. His current research interests are in the areas of student teacher preparation and societal inequalities, and early career teacher development and support, with a focus on partnership and mentoring.

\section{Eva Bjerkholt}

Eva Bjerkholt is an associate professor and head of the research group "Supervision, guidance and mentoring in education" at the Faculty of Humanities, Sports and Educational Science, University of South-Eastern Norway (USN). She is the leader and coordinator of the Norwegian Network for mentoring Newly Qualified Teachers (NQTs). The network consists of teacher educators and researchers from universities in Norway working with mentoring education and developing school based mentoring for NQTs in kindergartens and schools. The Ministry of Education finances the network, and the participants work together with the Directorate of Education and Training to develop sustainable induction and mentoring systems. She is also the leader of a cross-sectorial Nordic Network on induction and mentoring NQTs, financed by Nordplus horizontal. The members in this network are researchers on mentoring NQTs from universities and representatives from the teacher unions in the different Nordic countries. Eva is the convener of the Nordic Educational Research Association's network 25; Guidance, Counselling and Mentoring. Her doctoral thesis is a case study on the content and dialogues in mentoring NQTs. Today, she is the leader of one of USNs strategical research projects on learning environment and partnership in teacher education. 


\section{A comparative study of mentoring for new teachers in Europe}

Abstract

Teacher shortages and retention problems occur globally. This paper explores support for Newly Qualified Teachers (NQTs), in particular the role of mentoring. Reasons for mentoring NQTs include combating isolation and fostering collaboration, enhancing professional practice and retaining teachers in the profession. Three different national environments are compared, with teacher induction programmes at national and local levels providing support for NQTs. We contrast the situation in Scotland, an early adopter of a national teacher induction scheme (2002), with that of Malta where an induction programme has been in place since 2010 and Denmark where there is no national scheme, but some support may be organised at a municipal or school level. In all three countries challenges were found in the enactment of mentoring such as having time for observation and feedback but also in terms of how to mentor. Based on our findings we propose that both mentors and NQTs need time away from their teaching commitments to devote to their mentoring relationship. Furthermore, it would appear from our analysis that while a national induction scheme is important to promote the induction of NQTs, support for the transition into the teaching profession also depends on the individual school context.

Keywords: Comparative research; Mentoring; Newly Qualified Teachers; Teacher induction.

\section{Introduction}

In this paper we are focussed on the experience of new teachers. The first years of teaching are a crucial time while Newly Qualified Teachers (NQTs) establish themselves in their new career, begin unfamiliar and challenging working patterns, and develop attitudes to their role and work (Eick 2002; Flores 2001). Experiences as an NQT will depend on many factors, such as the nature of the school environment, the relationship between the NQT and their colleagues, and how the NQT draws on their initial teacher preparation 
to understand their experiences (Berry 2004; Langdon 2014). It is useful to explore what difference a structured national induction scheme makes in this pivotal period of development. Regular observation, feedback sessions, appropriate non-contact time, a positive school ethos towards professional growth, and support from mentors, all contribute to new teacher retention and provide a bridge from being a student teacher to a new teacher and from induction to early career professional learning (Ashby et al. 2008).

Exposure to these conditions may enhance teacher retention and teacher motivation in the longer term (ibid).

Ingersoll and Strong's (2011) review on induction and mentoring programmes for NQTs found that, overall, there is empirical support for the claim that induction support and, in particular, mentoring programmes have a positive effect. New teachers who took part in an induction programme had higher rates of satisfaction, commitment to teaching and retention (ibid). The reviewed studies also showed that both the teachers in induction schemes and their pupils performed better than their counterparts outside induction (ibid). Support for NQTs can provide opportunities to combat isolation (Schuck et al. 2018), foster collaboration (Greene 2014) and professional growth (McNally 2016). This paper explores how, in three parts of Europe (Scotland, Malta and Denmark), NQTs' transition into the teaching profession is supported, in particular through mentoring.

Using a case study approach, data was re-examined from country-specific research studies that had already been published (references removed for peer review process). Our studies entail an examination of induction and mentoring through the eyes of different stakeholders which is rare (Langdon et al. 2014). An earlier study compared induction in several European countries but did not include Denmark, Malta or Scotland (Valenčič Zuljan and Marentič Požarnik 2014). The countries in the current study have different teacher induction histories and contexts and teacher retention is an issue in all three places. In Scotland, a recent Scottish Parliament Committee report has noted that retention levels need to be improved (Scottish Parliament Education and Skills Committee, 2017). In Denmark, one out of six NQTs leaves the profession within the first year and the proportion is even higher in fringe municipalities (reference removed). Teachers in Denmark leave for 
different reasons, but working conditions, in relation to not feeling being able to do a good job, play a major role for many (Vaaben et al. 2009, p.25). In Malta, there are shortages of teachers in certain subjects and teacher retention is a problem due to competing job opportunities in the private sector. The Malta Union of Teachers claims that teachers in Malta need to be incentivized to remain in the job as the current salary and working conditions are no longer as attractive as they used to be (Bonnici, 2017).

Low retention rates of NQTs may have important implications for schools and their students. There are various research studies addressing teacher attrition and exit patterns (DeAngelis and Presley 2011; Skaalvik and Skaalvik 2011; Ronfeldt and McQueen 2017) and others in which the levels and nature of support provided to NQTs, such as induction and mentoring, (Hudson 2012; Ibrahim 2012) are investigated. These studies contribute to the knowledge on why teachers leave, and how the right support structures can help alleviate this phenomenon. In Parker et al.'s (2009) study of 8838 mentored teachers, NQTs who received 'a lot' of support were more likely to stay in teaching than those who received 'some' support. Ronfeldt and McQueen (2017) found that having a mentor reduced the chance of leaving teaching by 35 to $50 \%$ and that the effects of induction supports are significant across the first 5 years of teaching. While the societal, cultural, economic and political factors are important to explain variations in teacher retention across countries (Darling-Hammond and Rothman 2011), there are also individual-level factors such as teacher demographics and burnout (Borman and Dowling 2008), often influenced by important school-level factors such as administrative support (Boyd et al. 2011).

We will now consider the literature on teacher induction and specifically the mentoring of NQTs as a support mechanism for the transition into teaching and how induction and mentoring can enhance professional practice; and combat isolation and foster collaboration.

\section{Review of literature}


NQTs need a professional community to support them during their critical early career phase (Simos 2013). There is a high rate of teacher attrition for NQTs (Tamir 2010) and this may be exacerbated by the lack of acknowledgement of how challenging it is at the beginning of the teaching career (Spooner-Lane 2017). It is difficult for NQTs to ask for help, as they do not wish to appear weak in comparison to their colleagues and may think they do not have a right to support (Haggarty and Postlethwaite 2012). In addition, there can be differences in how schools interpret 'support', and some may use a checklist approach even when there is a national scheme for new teachers (reference removed). New teachers in supportive environments are more likely to ask for advice and also to overcome difficulties more effectively (Flores 2001).

Mentoring is seen as one of the most important components in induction programmes (Bullough 2012; Langdon et al. 2014) whereby prospective and NQTs are guided to develop knowledge about practices of teaching, and develop a professional identity (Ingersoll and Strong 2011). A mentor is usually understood to be a more experienced teacher who shares their knowledge and supports someone with less experience (Barrera et al. 2010; Harrison et al. 2006). The mentor may have multiple roles as they provide support, induct the NQT into their new workplace environment and guide their professional development (ibid). As Kardos and Johnson (2010) put it, 'mentoring, when done right, can stabilise the shifting ground on which new teachers try to stand' (p.24).

Induction programmes involving mentors can produce positive differences in teacher retention (Kukla-Acevedo 2009). While there are various models of mentoring, in this paper we have focused on mentoring through reflective practice as proposed by theorists such as Dewey (1910) and Schön (1983 and 1987). Reflection can scaffold critical review and support the development of NQTs' practice - a process that can be traced back to the development of constructivist interpretations of learning. For this to take place, mentors themselves should be reflective practitioners, and their key role is to provide the structural support for NQTs to reflect on their actions and systematically develop their perspectives on teaching and learning (Bleach 1997; Lunenberg et al. 2007). Rather than simply offering coping strategies and survival techniques, mentors can maintain the problematic nature of teaching and lay the foundation for critical appraisal of one's classroom practices and beliefs (Edwards et al. 2002).

It has been argued that schools need to recognise the pivotal role of induction mentors who provide both professional and pastoral support (Harrison et al. 2006). The school mentor should be available for informal discussions as well as for structured 
meetings, for example at break times with 'ease-of-access' to the mentor for both informal and formal interactions (Harrison et al. 2006, p.1065). It should be noted that teachers with management responsibilities may struggle to meet their mentees (Le Maistre 2010).

\section{Enhancing Professional Practice}

Mentoring is widely recognised as an important adjunct to teaching, because it influences and fosters the intellectual development of learners (Kamvounias et al. 2008). The teacher mentor has an impact on the mentee's practices (Hobson et al. 2009), particularly through discussion, modelling teaching and providing feedback (Clarke et al. 2013). Effective mentoring can also lead to better morale, increased willingness to take risks, more effective problem-solving strategies, improved classroom management and organisation, and more effective instructional strategies (Moir et al. 1999).

The NQT's professional development requires educational mentoring (Bradbury 2010) comprising developing pedagogical knowledge and skills, as well as shaping professional identity in terms of values and norms towards teaching, learning and colleagues (European Commission 2010). Working in the classroom implies exercising a series of professional judgments, a skill that develops in close interaction with practice, from experience in practice and from first-personexperiences acquired after qualifying as a teacher (Grimen and Molander 2008). Sensitive mentor-mentee discussions uncovering essentials and 'unessentials', assessing consequences of an action and taking necessary measures in difficult situations are critical (Bradbury 2010), and promote reflection and critical thinking (reference removed). Heikkinen et al. (2018) discuss the possibilities of transformations through social action and the creation and recreation of practices through mentoring. However, just as someone may exercise their free will by choosing to follow their mentor or colleagues' practice, they may decide not to follow and to learn in a different way (Billett and Somerville 2004). Not all NQTs will be involved in transformational learning with their mentor or other colleagues for various reasons. New entrants to a profession will look to identify with their buddy or mentor but if that person has very different views on the work this may put the new worker off the job completely (ibid). 


\section{Combating Isolation and Fostering Collaboration}

One of the earliest references to teacher isolation can be found in 'Schoolteacher: A Sociological Study' in 1975 when Lortie identifies isolation as a major cause of new teacher attrition. The 'cellular nature of schools' fosters independence and self-reliance but discourages collaboration $(1975$, p. 14). Professional isolation is a challenge that NQTs face (Simos 2013). Many teachers work alone in their classrooms, are physically isolated from their peers, and thus, peer support is unavailable to them (Gordon and Maxey 2000). They begin their careers in a new classroom setting and are faced with an unfamiliar professional culture (Berry 2004). They have few opportunities to reflect on instruction, co-teach or plan lessons with colleagues (Kardos and Johnson 2007). Bradbury and Koballa (2008) refer to teachers' 'culture of isolation', mentors not wanting to take over, NQTs reluctant to ask for help, being unimpressed with their mentor's advice or both seeking to avoid conflict. A feeling of isolation may occur even though the NQTs have a mentor and collaborative colleagues (Berry 2004; Simos 2013). The induction phase is demanding, and the NQTs' challenges are different from more experienced teachers' challenges (Smeby and Mausethagen 2017; Spooner-Lane 2017).

When looking at the induction period from the NQTs' perspective, the fact that school colleagues and leaders often represent a different and older generation needs to be taken into account (Lortie 1975; Rhodes et al. 2004) as this can also be a reason why some NQTs feel lonely. Different generations have different experiences and competencies and may often possess different beliefs and values (Krahn and Galambos 2013). The NQTs' competence in terms of their understanding of pupils' backgrounds could, if valued in the professional environment at school, give critical perspectives into discussions on developing professional practice (Bleach 1997; Lunenberg et al. 2007; reference removed). Establishing local networks and peer-mentoring groups with NQTs may strengthen their self-confidence and encourage them to share their reflections with their colleagues at school and in that way combat isolation and foster collaboration (Engvik and Emstad 2017). The quality of NQTs' relationships with colleagues plays a major role, especially the quality of relationship with their mentor (Hobson et al. 2007). One influence on the relationship is the mentor's competence in mentoring (Kardos and Johnson 2010; Lôfström and Eisenschmidt 2009).

Induction and mentoring are multi-dimensional and NQT learning is 'a collaborative, complex and systemic enterprise' (Langdon et al. 2014, p.104). Teachers often 
learn best from and with other teachers, when they trust each other and collaborate (Heikkinen et al. 2012). Collaboration minimises teachers' isolation and fosters dialogue and discussion (Rhodes et al. 2004). Structured collaboration between mentors and NQTs affects the NQTs' teaching practice (Williams et al. 2001) as it supports their learning (Eick 2002). They develop a strong disposition towards emergent learning communities, continuing to collaborate with peers within and across schools in subsequent years (Bickmore 2013) and thus also reflecting on their practice. Fantilli and McDougll (2009) discovered that collaboration with experienced subject or stage colleagues, team-teaching and informal mentoring formed a major part of the most significant support for new teachers' development. New teachers need good quality interpersonal relationships in and around the school so that they have the chance to ask for advice and talk over issues and micropolitical literacy so that they can fully understand workplace relations (Kelchtermans and Ballet 2002, reference removed). One way to ensure a good fit is to attempt to match mentors and NQTs. Effective criteria for achieving a good match have been found to be year or grade level, subject or content area (Lee and Feng 2007) and school building (Parker et al. 2009). Providing mentors that are able to discuss year or subject matter with the NQT, and who are in close physical proximity to them, could increase the level of support they are able to provide in everyday contact with the new teacher. Harrison, et al. (2006) refer to an ideal scenario in which both the needs of the school and the NQT are accommodated leading to the new teacher feeling more empowered in their work. However, some schools need to improve NQT experiences, with school leaders and staff working together to welcome and support NQTs (Schuck et al. 2018).

\section{Induction Landscape}

A comparative overview of each country's context is provided, beginning with Scotland as it has a long-established national induction scheme, followed by Malta which has a newer one, and then Denmark which has no national scheme.

\section{Scotland}

A national Teacher Induction Scheme (General Teaching Council for Scotland, 2012) was introduced in 2002. Eligible graduates from teacher education programmes in Scotland are guaranteed a one-year teaching post in a school, a reduced timetable of $80 \%$ of normal teaching duties, opportunities for Continuing Professional Development (CPD), and a designated induction supporter/mentor. NQTs are 
expected to meet with their mentor every week for the first half of their year. Mentors are meant to support NQTs and, along with the head teacher, assess their performance through observations and determine if they comply with all the parts of the Standard for Full Registration (ibid). Professional development activities are provided by NQTs' municipality employers. Municipalities are provided extra funding which is meant to be given to schools with mentors so that they have a reduced teaching load in order to devote $10 \%$ of their time on mentoring duties. No qualification, nor specific training nor length of practice is required to be a mentor in the Teacher Induction Scheme. It is up to teachers to volunteer to be a mentor. For those who do not join the Teacher Induction Scheme there is a Flexible Route to Full Registration which does not include a mentor or reduced class contact time. There are recognised teacher shortages in Scotland, in some rural areas and some subjects, in particular in mathematics and science subjects, and recently twelve new routes into teaching have been created to recruit more teachers (Muir, 2018).

\section{Malta}

Becoming a qualified teacher in Malta requires one to possess a First Degree in the subject area s/he is intending to teach, and study for the Masters in Teaching and Learning (MTL) with the Faculty of Education at the University of Malta. Once qualified, there is a two-year induction and mentoring programme through a teacher induction and mentoring policy and strategy. This programme was launched by the Quality Assurance Department in October 2012 for NQTs in the state sector (Quality Assurance Department, 2012). This phase precedes the award of a permanent teachers' warrant. The mentor allocated with the NQT will meet the mentee a few times in the first year of teaching to support and offer guidance, and the NQT can ask for this mentoring to continue into the second year of induction. For a number of years, teachers undertook a short training programme for prospective mentors offered by the Ministry of Education. From September 2016, mentor training has been formalised by the Faculty of Education at the University of Malta, and teachers aspiring to become mentors can undertake a Postgraduate Certificate in Educational Mentoring. Successful completion of this qualifies them to mentor student-teachers following the Masters in Teaching and Learning (MTL) and while on placement in schools; and NQTs during their induction period. Currently Maltese schools are faced with teacher shortages in several areas, particularly in the primary sector, and Mathematics, Sciences and ICT (Information and Communication Technology) in the secondary sector. This is due to two main 
reasons - teaching is regarded as a less attractive profession compared to other opportunities which have better pay and working conditions; and a significant number of teachers are disposed to leave the classroom for their career progression, or to leave the profession entirely (reference removed). In one study only $18 \%$ of 755 teachers participants preferred to remain in the classroom (reference removed). The Maltese career system favours recruitment rather than retention, considering the small gaps in pay and allowances between early career teachers and those with longer experience. It also favours low rather than high involvement, considering the lack of incentives for those who dedicate more efforts to teaching. Teacher retention is thus all the more crucial in a scenario where underqualified teachers are being recruited to fill these gaps.

\section{Denmark}

On a national level, Denmark has neither a programme nor a policy on teacher induction making it a general expectation that NQTs are capable of carrying out teaching in all its aspects from day one. Consequently, the support for NQTs is arbitrary and appears different from municipality to municipality and even varies from school to school, as municipalities rarely develop policies on teacher induction for their schools (Danmarks Evalueringsinstitut 2011, reference removed). Surveys show that approximately $40 \%$ of NQTs have an assigned mentor, some municipalities and some schools reduce the weekly timetable for NQTs, and NQTs may have to teach out of their field rather than teaching their specialist subject/s (ibid).

A recent survey shows that almost half of NQTs experience a lack of structure and framing regarding their induction (reference removed) and only a small proportion of NQTs with assigned mentors report that their mentorship is well-framed (ibid). In Denmark, a relatively large number of NQTs leave teaching after one or two years, a fact that is gradually putting teacher induction and career guidance on the agenda - the latter being almost non-existent (ibid).

The table below provides an overview and comparison of the three countries' contexts.

[Table 1 near here]

This comparison led us to the following research question:

How does mentoring for NQTs in Denmark, Malta and Scotland support their transition into the teaching profession? 


\section{Methodology}

This paper brings together previous studies in three countries. The Scottish study explored the perspectives of NQTs, their mentors and university tutors on a new partnership initiative which provided opportunities for NQTs to undertake an enquiry project as part of their CPD (reference removed). The aim of the original study in Malta was to evaluate mentors' perceptions of whether NQTs were adequately supported in their induction phase and whether the mentors felt they had adequate skills to support them (reference removed). The Danish study explored the variety of existing induction programmes with a special focus on the practice of mentoring (reference removed). (Please refer to the individual studies cited above for an explanation of their methodologies).

[Table 2 near here]

The comparative approach employed can be described as a cross case analysis (Yin 2009). After having completed our original studies we realised we had similar but not identical sets of data on NQT experiences. We identified the common and different features of the schemes in each of the three countries and we each conducted secondary analysis of our research findings to look at how support for NQTS can combat isolation and foster collaboration, and enhance professional growth. This re-analysis enabled a comparison of three different approaches to the induction and support of NQTs. Due to ethical and language issues we did not share our raw data, instead we shared our anonymized research findings translated into English.

Ethical approval was granted for the initial studies by the relevant authorities and to ensure compliance we did not share full data sets.

Synthesizing and summarizing research in any field is challenging (Higgins and Katsipataki 2016), and in educational research, scope, scale and sheer diversity make this challenge even greater. Yet, comparative and international research in education has a well-established history, and much can be gained from a critical analysis of multiple sites. Generally, comparisons in the educational field are underpinned by a hard currency of statistical indicators derived from educational surveys, and policy documents refer to these surveys to justify that the 'action' proposed has been proven to work in other systems. In this article we take a different approach, by combining the descriptions and case studies of three 
different contexts to highlight the effects of mentoring for the NQTs. Although the empirical studies carried out are different, they can still provide comparative inferences in this field of teacher induction and help us identify what we can promote in each system and offer recommendations for best practices.

As stated, cross case analysis which brings together research studies has limitations relating to this approach, such as comparing data gathered by different methods, and also related to any defects inherent in its constituent parts. For example, one of the limitations of the Maltese study is that it is solely focusing on the perceptions of the participating teacher mentors, the Scottish study only involved participants in two municipalities whereas in Denmark, a national survey was conducted with focus groups as part of a design-based research project.

\section{Findings}

The original findings from the three research projects have been explored for this study through a re-analysis of the data by the original researchers. Illustrative quotations have been provided to show the types of comments made within each theme. The two themes of enhancing professional practice and combating isolation and fostering collaboration, were chosen as in our lengthy online discussions we could see that these were common themes emerging from our data.

\section{Enhancing Professional Practice}

In Denmark NQTs with a mentor assigned to them felt significantly better equipped than NQTs without a mentor with respect to planning and teaching, classroom management, working with children with special needs and teamwork. Furthermore, those with mentors reported that their job start was better framed and structured. Opportunities to reflect on practice on a regular basis, often connecting with observation, were highlighted by mentors and NQTs, for example in Malta:

We generally had meetings before a lesson, follow-up meetings discussing the observed lesson/s and later also reflective sessions discussing focus areas of this practice (Mentor, Malta).

The nature of mentoring was found to be influential in supporting growth, with clear and balanced scaffolded questioning, different activities providing a focus for 
mentoring and a range of timely and effective advice. However, there are challenges if meetings are difficult to arrange.

but really, you have to get the meetings in a schedule.... Otherwise, you don't get what you need... There have been times where I didn't know that I needed my mentor (NQT, Denmark)

How do I perform as a teacher? Is it good enough? It's hard to be without the feedback you're used to getting. It has to be systematic (NQT, Denmark)

Another challenge for mentors is that of finding the right balance between giving advice to the mentee and asking questions that will guide the mentee to find the answers:

She has been able to create a truly open and constructive dialogue - not just some chat, I often left the meeting with a 'Wow' ... (NQT, Denmark)

NQTs may have specific challenges in terms of their learning and professional growth because they are operating in complex and unfamiliar school settings. Mentoring activity is enhanced when actors understand their roles and responsibilities within a collaborative relationship, although this situation can often be compromised at a time when, globally, educational systems (at school and individual levels) are experiencing great change and placing additional demands on actors:

My mentor was very supportive ... she was restricted by the same issues revolving around free time in an understaffed school (NQT, Scotland)

The findings suggest that certain areas of professional practice are more challenging than others to support through mentoring, such as evaluative processes. There is evidence to suggest that mentors also grow professionally from involvement although this requires time for dialogue and reflection:

...becoming a mentor does not happen overnight. This is a long process which can ultimately only be achieved through reflective practice and ongoing conversation between mentor and mentee (Mentor, Malta). 
In Scotland mentors highlighted the learning dimension to the research project the NQTs undertook:

a learning curve on many levels, with the opportunity to work with other professionals from different organisations (Mentor, Scotland).

\section{Combating Isolation and Fostering Collaboration}

The NQTs pointed to the importance of developing practice within a supportive mentoring community, of discussing ideas, and sharing their experiences and knowledge. There was also evidence of how the NQTs and their mentors planned lessons together, discussed class-related issues, pooled resources and gave tips to each other 'over a cup of tea and a toast' or in more formal mentoring meetings:

Our team is a safety net. If someone is about to stumble three colleagues are ready to catch you right away. That's just cool. (NQT, Denmark).

NQTs valued the cumulative opportunities they had to share their research which generated further collegial learning:

The most valuable, constructive, helpful part ..., in informing my practice, was the event where we spoke to others about our topic. (NQT, Scotland).

The NQTs highlighted the importance of networking with other NQTs:

We are two NQTs at the same school. We face the same frustrations. It is easier to ask all the 'silly' questions to him or her. (NQT, Scotland).

Data in all three studies showed that NQTs, mentors and tutors from the university all commented on the benefits of collaboration and knowledge sharing for NQTs. For example, in Scotland, one university tutor said: 
[It enabled] engagement in cross sector discussion and a sharing of ideas, including the need for more opportunities for sharing information about teaching strategies (University tutor, Scotland).

An NQT in Scotland highlighted:

useful practical information gained through engagement in cross-sector discussion and sharing - same strategy, such as peer assessment, tried in different setting. (NQT, Scotland).

The Danish study showed that NQTs with a mentor felt, to a larger extent, that their schools gave priority to collaboration and knowledge-sharing (reference removed). One NQT stated:

Two teachers observing each other's teaching, that could be fab. But a colleague, not a leader - a colleague teaching the same subject. (NQT, Denmark).

In the Scottish study there was evidence of infrastructural challenges:

we were the ones trying to explain the situation to our probationer mentor and our subject mentor. (NQT, Scotland).

Mentors in the Scottish study reflected on the importance of having a shared vision and working towards jointly identified goals as a key element to build a solid collaboration between the NQTs and the mentors and between the NQTs, mentors and university tutors while a mentor in Malta emphasised the importance of individual personalities and the time needed for mentoring.

In my opinion, it is the attitudes and dispositions of the individual members that will determine the level of success of such collaborations. Such a relationship is not only professional but also personal and for this to be achieved, it will take quite some time. (Mentor, Malta).

\section{Discussion}


While the three countries are at different stages in relation to teacher induction programmes, each country has similar issues in relation to how to best support NQTs. All three countries are facing challenges in terms of teacher shortages so increased recruitment is required. However, in order to retain these new teachers in the profession, support for the transition into the teaching profession is necessary, otherwise these new recruits will not stay in teaching.

\section{Enhanced professional practice}

The three case studies provided a lens through which key aspects of teacher professional growth, notably the development of pedagogical knowledge and understanding, and the emergence of professional identity, could be viewed. Findings uncovered particular supporting characteristics of the mentoring processes, for both mentee and mentor. As in other studies, opportunities to reflect on practice on a regular basis were highly valued (removed for peer review purposes), as were clear and balanced scaffolded questioning, observation (Ashby et al. 2008), and a range of mentor advice scoping practical and affective dimensions (Moir et al. 1999).

The findings suggest that certain areas of professional practice are more challenging than others in terms of support through mentoring, such as evaluative processes. In the Scottish study, the participating NQTs, mentors and university tutors valued the opportunity to learn in a partnership community and the mentors highlighted the benefits and challenges of supporting NQTs to undertake enquiry in the classroom.

In relation to how support for new teachers can influence teacher retention, we reported on what new teachers themselves, their mentors and university tutors experienced. Several studies have shown how the level of support provided to NQTs can reduce teacher attrition (Hudson 2012, Ibrahim 2012), and the Danish study reported in this paper indicated that NQTs with a mentor felt more supported than those without a mentor. Furthermore, in the Danish study, new teachers whose mentor had received relevant mentor education or training expressed higher levels of feeling supported. Factors which affected the new teachers' support in the three case studies included macro level economic factors as found by Darling-Hammond and Rothman (2011). Kukla-Acevedo (2009) noted the influence of systemic factors such as whether there was a national induction programme, with or without a mentor, and this was found across our three cases. In Scotland and Malta where there are national induction programmes with mentors, more support was available than in Denmark where it is up to each municipality and school to decide on the support provided to NQTs. A key finding across all the three studies was the 
importance of the level of support for new teachers in school. Staffing shortages made this support more problematic in Scotland while in Denmark and Malta, school culture and institutional support were crucial factors in determining the level of support. Structures do not always provide the conditions for initiatives such as the enquiry focus in Scotland in terms of personnel or support. There is a need for an expansive learning environment at all levels (reference removed).

\section{Combating isolation and fostering collaboration}

Differences in systems and challenges point to the importance for policymakers, administrators, researchers and other stakeholders in teacher education to collaborate and learn from each other. It is evident that building a national structure is important, but not necessarily enough to create a sustainable system on induction and mentoring. Researchers collaborating with stakeholders like municipalities may develop prototypes for induction, but it is only one step towards a system that gives all NQTs the necessary support.

While mentoring is a key component in all three contexts, it is supported in different ways and to different degrees. In Scotland there is no requirement for teacher mentors to undergo any specific training (although such training does exist), in Malta all teacher mentors must now take part in a specialised university course which prepares teachers to offer support to their mentees. While there has been no formal evaluation of the Scottish induction scheme, research studies that have been carried out have shown the importance of relational and emotional, personal and professional supports (McNally and Blake 2010, Fenwick and Weir 2010, references removed). The Donaldson Report (2011) reinforced this theme, highlighting the importance of partnership with a broad range of stakeholders, alongside mentoring and tailored CPD activity. Recommendations included splitting mentors' support and assessment functions and mentor training (ibid) but these have not been implemented. While the scheme guarantees temporary fulltime employment immediately after teacher preparation programmes, uncertainty over employment has shifted from university to the induction year (reference removed).

NQTs who participated in the three studies point to the importance of discussing their experiences and sharing their demands and challenges with other new teachers in accordance with Haggarty et al. 's study (2011). Danish NQTs reported that, in general, their inputs and contributions were valued by colleagues and leadership. 
All three studies suggest that any induction programme needs to be endorsed by the school leadership team and be part of a policy of developing collaborative school cultures (reference removed).

\section{Conclusion}

It is well-established that induction and mentoring reduce the attrition of NQTs. Here we have compared the differing induction contexts of Denmark, Malta and Scotland for the first time. We have found that school context and mentoring are more important than a national induction framework per se.

The evaluation of the three research studies supports the following recommendations. Firstly, for an effective system of NQT mentoring, it is important that mentors are allocated sufficient time for them to meet their mentees; observe their lessons and give them feedback; that NQTs observe mentors' and/or other colleagues' lessons; and engage in reflective practice. Secondly, it is important that members of the school leadership team, and the education authorities, appreciate what NQT mentoring entails in order to provide the required support, in terms of relieving mentors of some of their daily tasks to allow them to go in the NQTs' classes, and helping to foster a culture of collaboration in schools. When the school community understands what the needs of the NQTs are and how they are working with their mentors, they will be far more willing to collaborate and support these new teachers. Thirdly, NQTs need to be allocated a lighter working load, at least in their first year of teaching, so as to allow them to focus on their professional growth and visit their mentors' classrooms and observe their practice more regularly.

We suggest that the mentoring approach to be adopted should be one of inquiry as proposed by Slavit and Nelson (2010). This will require more time to observe lessons and reflect on practice, but such support will facilitate a process whereby the NQT explores effective strategies and be receptive to experiment on varied routes for success, rather than resort to ways of surviving with learning new things and coping with a full teaching schedule. Mentoring for research in the classroom may be an important addition to mentor training programmes as found in the Scottish study.

This meta-perspective of support for NQTs in three countries highlights the complexity of this phenomenon and that it requires more than a national, written-down, scheme. This research has shown the commonalities between countries and points towards what is needed in terms of policy and implementation, in order to have conditions 
that welcome and support NQTs in their transition into the teaching profession. Whether there is a national teacher induction scheme or not, does not appear to be as important as the infrastructure of support, training and education involved and how support is shared and communicated. Whatever model is in place, an authentic partnership between schools, NQTs and mentors that anchors new teachers into the teaching profession is needed.

\section{Acknowledgements}

The research conducted in Scotland was funded by the Scottish Government 


\section{References}

Ashby, P., Hobson, A.J., Tracey, L., Malderez, A., Tomlinson, P.D., Roper, T., Chambers, G.N., and Healy, J., 2008. Beginner teachers' experiences of initial teacher preparation, induction and early professional development: A review of literature.

DCSF, GTC and TDA. DCSF Research Report No. RW076. Available online: http://publications.dcsf.gov.uk/eOrderingDownload/DCSF-RW076.pdf

Barrera, A., Braley, R.T., and Slate, J.R., 2010. Beginning teacher success: an investigation into the feedback from mentors of formal mentoring programs. Mentoring \& Tutoring: Partnership in Learning, 18 (1), 61-74. DOI:

$10.1080 / 13611260903448383$

BEK nr. 1068 af 08/09/2015. Bekendtgфrelse om uddannelsen til professionsbachelor som laerer i folkeskolen. Undervisningsministeriet.

Berry, B., 2004. Recruiting and retaining "highly qualified teachers" for hard-to-staff schools. NASSP Bulletin 88, 5-27.

Bickmore, D.L., 2013. Professional development and the middle school concept: A reciprocal relationship. In P. G. Andrews (Ed.), Research to guide practice in middle grades education. 4, 717-749. Westerville, $\mathrm{OH}$ : Association for Middle Level Education.

Billett, S. and Somerville, M., 2004. Transformations at work: Identity and Learning. Studies in Continuing Education, 26 (2) 309-326.

Bleach, K., 1997. The importance of critical self-reflection in mentoring newly qualified teachers. Mentoring and Tutoring, 4 (3), 19-24.

Bonnici, J., 2017. Teachers need to be provided with proper salary that reflects their profession - MUT president. The Malta Independent. Retrieved June 17, 2018, from http://www.independent.com.mt/articles/2017-10-02/local-interviews/Teachers-need-tobe-provided-with-proper-salary-that-reflects-their-profession-MUT-president6736179665 
Borman, G.D. and Dowling, N. M., 2008. Teacher attrition and retention: A metaanalytic and narrative review of the research. Review of Educational Research, 78 (3), 367-409.

Boyd, D., Grossman, P., Ing, M., Lankford, H., Loeb, S. and Wyckoff, J., 2011. The influence of school administration on teacher retention decisions. American Educational Research Journal, 48 (2), 303-333.

Bradbury, L.U., 2010. Educative mentoring: Promoting reform-based science teaching through mentoring relationships. Science Education, 94 (6), 1049-1071. https://doi.org/10.1002/sce.20393

Bradbury, L.U. and Koballa, T.R., 2008. Borders to cross: Identifying sources of tension in mentor-intern relationships. Teaching and Teacher Education, 24 (8), 21322145.

Bullough, R.V., Jr., 2012. Mentoring and new teacher induction in the United States: a review and analysis of current practices. Mentoring \& Tutoring: Partnership in Learning, 20 (1), 57-74.

Clarke, M., Killeavy, M. and Moloney, A., 2013. The genesis of mentors' professional and personal knowledge about teaching: Perspectives from the Republic of Ireland. European Journal of Teacher Education, 36 (3), 364-375.

Danmarks Evalueringsinstitut. 2011. Ny laerer. Retrieved from https://www.eva.dk/grundskole/lærer

Darling-Hammond, L. and Rothman, R., 2011. Lessons learned from Finland, Ontario, and Singapore, in Darling-Hammond, L. and Rothman, R. (Eds.), Teacher and leader effectiveness in high performing education systems. The Alliance for Excellent Education, Stanford, CA, 1-13.

DeAngelis, K.J. and Presley, J.B., 2011. Toward a more nuanced understanding of new teacher attrition. Education and Urban Society, 43 (5), 598-626.

Dewey, J., 1910. How we think. Lexington, MA: Heath. 
Donaldson, G., 2011. Teaching Scotland's Future. Report of a review into teacher education in Scotland. Edinburgh: Scottish Government.

Edwards, A., Gilroy, P. and Hartley, D., 2002. Rethinking teacher education, collaborative responses to uncertainty. London: Routledge Falmer Press.

Eick, C., 2002. Studying Career Science Teachers' Personal Histories: A Methodology for Understanding Intrinsic Reasons for Career Choice and Retention. Research in Science Education, 32 (3), 353-372.

Engvik, G. and Emstad, A., 2017. The importance of school leaders' engagement in socializing newly qualified teachers into the teaching profession. International Journal of Leadership in Education, 20 (4), 468-490.

European Commission, 2010. Developing coherent and system-wide induction programmes for beginning teachers: a handbook for policymakers. Retrieved from http://ec.europa.eu/dgs/education_culture/repository/education/policy/school/doc/handb ook0410_en.pdf

Fantilli, R.D. and McDougall, D.E., 2009. A study of novice teachers: Challenges and supports in the first years. Teaching and Teacher Education, 25 (6), 814-825.

Fenwick, A. and Weir, D., 2010. The impact of disrupted and disjointed early professional development on beginning teachers. Teacher Development: An international journal of teachers' professional development, 14 (4), 501-517.

Flores, M.A., 2001. Person and Context in Becoming a New Teacher. Journal of Education for Teaching, 27 (2), 135-148. DOI: 10.1080/02607470120067882

General Teaching Council for Scotland (GTCS), 2012. Policy and GuidanceProvisional Registration and Probationary Service. Edinburgh: General Teaching Council for Scotland.

Gordon, S.P. and Maxey, S., 2000. How to help beginning teachers succeed, 2nd ed., Baltimore, MD: Association for Supervision and Curriculum Development. 
Greene, K., 2014. Finding connections: The power of collegial conversations and collaboration. (mentoring new English teachers) (High School Matters). English Journal, 103 (5), 12.

Grimen, H. and Molander, A., 2008. Profesjon og skjønn. In A. Molander and L.T. Terum (Eds.) Profesjonsstudier, 179-196. Oslo: Universitetsforlaget.

Haggarty, L., Postlethwaite, K., Diment, K., and Ellins, J., 2011. Improving the learning of newly qualified teachers in the induction year. British Educational Research Journal, 37 (6), 935-954.

Haggarty, L. and Postlethwaite, K., 2012. An exploration of changes in thinking in the transition from student teacher to newly qualified teacher. Research Papers in Education, 27 (2), 241-262.

Harrison, J., Dymoke, S. and Pell, T. 2006. Mentoring beginning teachers in secondary schools: An analysis of practice. Teaching and Teacher Education, 22 (8), 1055-1067. doi: 10.1016/j.tate.2006.04.021

Heikkinen, H.L.T., Jokinen, H., and Tynjälä, P. (eds.), 2012. Peer-group mentoring for teacher development. London: Routledge.

Heikkinen, H.L.T., Wilkinson, J., Aspfors, J. and Bristol, L., 2018 Understanding mentoring of new teachers: Communicative and strategic practices in Australia and Finland. Teaching and Teacher Education, 71, 1-11. https://doi.org/10.1016/j.tate.2017.11.025

Higgins, S. and Katsipataki, M., 2016. Communicating Comparative Findings from Meta-Analysis in Educational Research: Some Examples and Suggestions. International Journal of Research \& Method in Education, 39 (3), 237-254.

Hobson, A.J., Ashby, P., Malderez, A. and Tomlinson, P.D., 2009. Mentoring beginning teachers: What we know and what we don't, Teaching and Teacher Education, 25 (1), 207-216.

Hobson, A.J., Malderez, A., Tracey, L., Homer, M.S., Mitchell, N., Biddulph, M., Giannakaki, M.S., Rose, A., Pell, R.G., Roper, T., Chambers, G.N. and Tomlinson, 
P.D., 2007. Newly Qualified Teachers' Experiences of their First Year of Teaching. Findings from Phase III of the Becoming a Teacher Project. DCSF-RR008.

Nottingham: Department for Children, Schools and Families.

Hudson, P.B., 2012. Beginning teachers' achievements and challenges: implications for induction and mentoring, in Proceedings of the 2012 Annual Australian Teacher Education Association (ATEA) conference, Australia. Australia: Australian Teacher Education Association (ATEA).

Ibrahim, A.S., 2012. Induction and mentoring of novice teachers: A scheme for the United Arab Emirates. Teacher Development, 16 (2), 235-253.

Ingersoll, R.M. and Strong, M., 2011. The impact of induction and beginning programs for beginning teachers: A critical review of the research, American Education Research Association, 81 (2), 201-233.

Kamvounias, P., McGrath-Champ, S. and Yip, J., 2008. 'Gifts' in mentoring: mentees' reflections on an academic development program, International Journal for Academic Development, 13 (1), 17-25.

Kardos, S.M., and Johnson, S.M., 2007. On their own and presumed expert: New teachers' experience with their colleagues. Teachers College Record, 109, 2083-2106.

Kardos, S.M. and Johnson, S.M., 2010. New Teachers' Experiences of Mentoring: The Good, the Bad, and the Inequity. Journal of Educational Change, 11 (1), 23-44.

Kelchtermans, G. and Ballet, K., 2002. The micropolitics of teacher induction. A narrative-biographical study on teacher socialisation. Teaching and Teacher Education, 18 (1), 105-120.

Krahn, H.J., and Galambos, N.L., 2013. Work values and beliefs of 'Generation X' and 'Generation Y', Journal of Youth Studies, 17 (1), 92-112.

Kukla-Acevedo, S., 2009. Leavers, Movers, and Stayers: The Role of Workplace Conditions in Teacher Mobility Decisions. The Journal of Educational Research, 102 (6), 443-452. 
Langdon, F.J., Alexander, P.A., Ryde, A. and Baggetta, P., 2014. A national survey of induction and mentoring: How it is perceived within communities of practice, Teaching and Teacher Education, 44, 92-105.

LBK nr 1510 af 14/12/2017. Bekendtgфrelse af lov om folkeskolenUndervisningsministeriet.

Lee, J.C. and Feng, S., 2007. Mentoring support and the professional development of beginning teachers: a Chinese perspective. Mentoring \& Tutoring: Partnership in Learning, 15 (3), 243-262.

Le Maistre, C., 2010. Whatever it takes: How beginning teachers learn to survive. Teaching and Teacher Education, 26 (3), 559-564.

Löfström, E. and Eisenschmidt, E., 2009. Novice teachers' perspectives on mentoring: The case of the Estonian induction year. Teaching and Teacher Education, 25 (5), 681689.

Lortie, D., 1975. Schoolteacher: A sociological study. Chicago: The University of Chicago Press.

Lunenberg, M., Korthagen, F. and Swennen, A., 2007. The teacher educator as a role model, Teaching and Teacher Education. 23 (5), 586-601.

McNally, J.C., 2016. Learning from one's own teaching: New science teachers analyzing their practice through classroom observation cycles, Journal of Research in Science Teaching. 53 (3), 473-501.

McNally, J. and Blake, A., 2010. Improving Learning in a Professional Context. A research perspective on the new teacher in school. London: Routledge.

Moir, E., Gless, J. and Baron, W., 1999. A support program with heart: The Santa Cruz project, in Scherer, M. (Ed.), A better beginning: Supporting and mentoring new teachers, Association for Supervision and Curriculum Development, Alexandria, VA, $106-115$.

Muir, K., 2018. Radical actions needed to solve our teacher shortage. Retrieved from http://www.gtcs.org.uk/News/teaching-scotland/75-radical-actions.aspx 
Parker, M.A., Ndoye, A. and Imig, S.R., 2009. Keeping our teachers! Investigating mentoring practices to support and retain novice educators. Mentoring \& Tutoring: Partnership in Learning, 17 (4), 329-341.

Quality Assurance Department, Malta, 2012. Guidelines on how to use the Performance Management and Professional Development Plan for Newly Qualified Teachers in their first year of practice. Malta: Ministry of Education and Employment.

Rhodes, C., Stokes, M. and Hampton, G., 2004. A practical guide to mentoring, coaching, and peer-networking: Teacher professional development in schools and colleges. London: RoutledgeFalmer.

Ronfeldt, M. and McQueen, K., 2017. Does New Teacher Induction Really Improve Retention? Journal of Teacher Education, 68 (4), 394-410. doi: $10.1177 / 0022487117702583$.

Schön, D.A., 1983. The reflective practitioner: How professionals think in action. San Francisco, CA: Jossey-Bass.

Schön, D.A., 1987. Educating the reflective practitioner. San Francisco, CA: JosseyBass.

Schuck, S., Aubusson, P., Buchanan, J., Varadharajan, M. and Burke, P.F., 2018. The experiences of early career teachers: New initiatives and old problems. Professional Development in Education, 49 (2), 209-221.

Scottish Parliament Education and Skills Committee, 2017. Teacher Workforce Planning for Scotland's Schools. SP Paper 186. Scottish Parliament: Edinburgh. Available at https://digitalpublications.parliament.scot/Committees/Report/ES/2017/9/1/TeacherWorkforce-Planning-for-Scotland-s-Schools\#Summary-of-Conclusions-andRecommendations

Simos, E., 2013. Why Do New Teachers Leave? How Could They Stay? English Journal, 102 (3), 100-105. 
Skaalvik, E.M. and Skaalvik, S., 2011. Teacher job satisfaction and motivation to leave the teaching profession: Relations with school context, feeling of belonging, and emotional exhaustion, Teaching and Teacher Education, 27 (6), 1029-1038.

Slavit, D. and Nelson, T.H., 2010. Collaborative teacher inquiry as a tool for building theory on the development and use of rich mathematical tasks. Journal of Mathematics Teacher Education, 13 (3), 201-221.

Smeby, J.-C. and Mausethagen, S., 2017. Profesjonskvalifisering. In S. Mausethagen and J.-C. Smeby Kvalifisering til profesjonell yrkesutфvelse, 9-20. Oslo:

Universitetsforlaget.

Spooner-Lane, R., 2017. Mentoring Beginning Teachers in Primary Schools: Research Review. Professional Development in Education, 43 (2), 253-273.

Svensson, L., 2004. Forskningsmetoders analytiska och kontekstuella kvaliteter. In C.M. Allwood (Ed.), Perspektiv på kvalitativ metod. Lund: Studentlitteratur.

Svensson, L., 2016. Kontextuell analys - en metodologi för forskning. In E. Anderberg (ed.), Skolnära forskningsmetoder, 191-216. Lund: Studentlitteratur.

Svensson, L.G. and Karlsson, A., 2008. Profesjoner, kontroll og ansvar. In A. Molander and L. I. Terum (Eds.) Profesjonsstudie, 261-278. Oslo: Universitetsforlaget.

Tamir, E., 2010. The Retention Question in Context-Specific Teacher Education: Do Beginning Teachers and Their Program Leaders See Teachers' Future Career Eye to Eye. Teaching and Teacher Education: An International Journal of Research and Studies, 26 (3), 665-678.

Vaaben, N.K., Böwadt, P.R. and Pedersen, R., 2016. Hvorfor stopper laererne I Folkeskolen? https://ucc.dk/sites/default/files/hvorfor_stopper_laererne.pdf

Valenčič Zuljan, M. and Marentič Požarnik, B., 2014. Induction and Early-career Support of Teachers in Europe. European Journal of Education, 49, 192-205. doi:10.1111/ejed.12080 
Williams, A., Prestage, S. and Bedward, J., 2001. Individualism to Collaboration: the significance of teacher culture to the induction of newly qualified teachers. Journal of Education for Teaching, 27 (3), 253-267.

Yin, R. K., 2009. Case study research: design and methods ( $4^{\text {th }}$ ed.). Los Angeles: Sage Publications.

Table 1. Overview of Induction Landscape in Scotland, Malta and Denmark.

\begin{tabular}{|c|c|c|c|}
\hline & Scotland & Malta & Denmark \\
\hline $\begin{array}{l}\text { Nature of } \\
\text { induction } \\
\text { programme }\end{array}$ & $\begin{array}{l}\text { National scheme since } \\
2002\end{array}$ & $\begin{array}{l}\text { National scheme in the } \\
\text { state sector since } \\
2010 \text {; varied } \\
\text { implementation efforts } \\
\text { in the state sector }\end{array}$ & $\begin{array}{l}\text { Local initiatives vary } \\
\text { depending on the local } \\
\text { school and } \\
\text { municipality }\end{array}$ \\
\hline $\begin{array}{l}\text { Length of } \\
\text { induction } \\
\text { programme }\end{array}$ & 1 year & 2 years & Locally defined \\
\hline $\begin{array}{l}\text { Mentoring } \\
\text { and support }\end{array}$ & $\begin{array}{l}\text { Mentor appointed, and } \\
\text { CPD programme } \\
\text { encompasses this } \\
\text { mentoring support }\end{array}$ & $\begin{array}{l}\text { Mentor appointed, and } \\
\text { CPD programme } \\
\text { encompasses this } \\
\text { mentoring support }\end{array}$ & $\begin{array}{l}\text { Locally defined - in } \\
\text { practice } 40-50 \% \text { of } \\
\text { NQTs have a } \\
\text { designated mentor }\end{array}$ \\
\hline $\begin{array}{l}\text { Mentor } \\
\text { education }\end{array}$ & None required & $\begin{array}{l}\text { Formalised, accredited } \\
\text { by University (from } \\
2016 \text { ) }\end{array}$ & None \\
\hline $\begin{array}{l}\text { Role of } \\
\text { universities }\end{array}$ & $\begin{array}{l}\text { No formal role so } \\
\text { involvement varies } \\
\text { depending on the } \\
\text { municipality and } \\
\text { university in question. }\end{array}$ & $\begin{array}{l}\text { Formalised national } \\
\text { agreement }\end{array}$ & $\begin{array}{l}\text { No formal role but } \\
\text { involvement in pilot } \\
\text { study research }\end{array}$ \\
\hline $\begin{array}{l}\text { Teacher } \\
\text { shortages }\end{array}$ & $\begin{array}{l}\text { In rural areas and } \\
\text { some subjects, in } \\
\text { particular in } \\
\text { mathematics, } \\
\text { computing science and } \\
\text { other science subjects } \\
\text { but also in Home } \\
\text { Economics. }\end{array}$ & $\begin{array}{l}\text { Maltese schools are } \\
\text { faced with teacher } \\
\text { shortages in several } \\
\text { areas, particularly } \\
\text { in the primary } \\
\text { sector, and } \\
\text { Mathematics, } \\
\text { Sciences and ICT } \\
\text { (Information and } \\
\text { Communication } \\
\text { Technology) in the } \\
\text { secondary sector. }\end{array}$ & $\begin{array}{l}\text { In some peripheral areas } \\
\text { Shortages will grow due } \\
\text { to the demographic } \\
\text { profile of the current } \\
\text { teaching force and } \\
\text { because approximately } \\
15 \% \text { of NQTs leave } \\
\text { school within their first } \\
\text { year of practice }\end{array}$ \\
\hline
\end{tabular}




\begin{tabular}{|l|l|l|l|}
\hline $\begin{array}{l}\text { Becoming a } \\
\text { qualified } \\
\text { teacher }\end{array}$ & $\begin{array}{l}\text { Successful completion } \\
\text { leads to Full } \\
\text { Registration as a } \\
\text { teacher }\end{array}$ & $\begin{array}{l}\text { Successful completion } \\
\text { leads to Permanent } \\
\text { Teachers' Warrant. }\end{array}$ & $\begin{array}{l}\text { No formal induction } \\
\text { scheme. Fully } \\
\text { qualified after ITE. }\end{array}$ \\
\hline
\end{tabular}

Table 2. A cross case analysis of the three studies

\begin{tabular}{|l|l|l|l|}
\hline & Scotland & Malta & Denmark \\
\hline $\begin{array}{l}\text { Research } \\
\text { design/ } \\
\text { approach }\end{array}$ & Qualitative & Grounded theory & Design-based \\
\hline Data & $\begin{array}{l}\text { Focus groups with } \\
\text { 10 NQTs, 6 mentors } \\
\text { and 3 university } \\
\text { tutors (2 } \\
\text { municipalities) }\end{array}$ & $\begin{array}{l}\text { Journal reflections of } \\
\text { mentors } \\
\text { Online forum } \\
\text { conversations of 10 } \\
\text { mentors }\end{array}$ & $\begin{array}{l}\text { Focus groups with 11 } \\
\text { NQTs }\end{array}$ \\
\hline $\begin{array}{l}\text { Documentation } \\
\text { Policy documents }\end{array}$ \\
$\begin{array}{l}\text { National quantitative } \\
\text { survey (n=1141) }\end{array}$ \\
\hline $\begin{array}{l}\text { Cross case } \\
\text { analysis }\end{array}$ & $\begin{array}{l}\text { Thematic analysis } \\
\text { through coding } \\
\text { and coding qualitative data. This was conducted as a cross-case analysis } \\
\text { (Svensson 2004 and 2016, Svensson and Karlsson, 2008) with the } \\
\text { researchers discussing their re-analysis and working together to identify } \\
\text { common themes. }\end{array}$ & $\begin{array}{l}\text { Content analysis to } \\
\text { code and categorise the } \\
\text { data }\end{array}$ & $\begin{array}{l}\text { Thematic analysis } \\
\text { Documentary analysis } \\
\text { Statistical analysis }\end{array}$ \\
\hline
\end{tabular}

